\title{
Land Administration in Zambia After 1991: History, Opportunities and Challenges From the 1995 Lands Act
}

\author{
Augrey H. Malambo ${ }^{1}$ \\ ${ }^{1}$ Department of Geography, University of Zambia, Lusaka, Zambia \\ Correspondence: Augrey H. Malambo, Department of Geography, University of Zambia, Lusaka, Zambia. Tel: \\ 260-09-6646-3139. E-mail: augrey.malambo@yahoo.com
}

Received: November 22, 2013

doi:10.5539/jgg.v6n1p139
Accepted: December 12, 2013 Online Published: February 22, 2014

URL: http://dx.doi.org/10.5539/jgg.v6n1p139

\begin{abstract}
The Land tenure system in Zambia is divided in the following administrative segments: colonial period 1880-1964; immediate post independence 1964-1975, post independence period of one party political administration 1975-1991; and the liberalization period of multiparty government of post 1991, with emphasis on the implications of the 1995 Lands Act. Generally, each period of land tenure administration provided local people relative opportunities and challenges. The aim of this study was to establish the history of, opportunities to and challenges faced by local people in Chibombo district emerging from the 1995 Lands Act. Primary data was obtained through questionnaires, interviews and observations between August 2008 and 2012 involving 60 smallholder farmers around Chibombo (39 respondents) and Mungule (21 respondents) areas of Chibombo district. Through this study it was concluded that several individuals, from within Chibombo district and elsewhere, had obtained title deeds on customary land based on the 1995 Lands Act. Dominantly, among the local people who managed to obtain title deeds to their pieces of land over 70 percent were men. Furthermore, through this policy shift new investments emerged on customary land including a cooking oil processing plant, filling stations and lodges, among others, and the local people benefitted through employment creation, improvements to their houses, purchase of solar panels, radios, cell phones and others. On the contrary, others reduced their land hectarage through selling of parts of their land for money, some relocated from their previous residence and evidence of land boundary conflicts was recorded. Therefore, a mixture of opportunities and challenges emerged from the introduction of the 1995 Lands Act.
\end{abstract}

Keywords: chief, chibombo farming block, chibombo district, customary/traditional land, district council, headman, land holding right, land owner, lands act (1995), leasehold title, katuba farming block, state land, title deed, Zambia

\section{Introduction}

\subsection{General Introduction and Background}

This study intended to provide an analysis of the implications of the 1995 Lands Act in Zambia. In order to achieve this goal, the study examined the prior Land Acts in Zambia from pre independence years of colonialism (1890-1964), through the period of one party rule of the United National Independence Party (UNIP) led by Dr. David Kenneth Kaunda (1964-1990), up to the time of economic liberalization and multi-party politics under the administration of the Movement for Multiparty Democracy (MMD) led by Dr. Frederick J. T. Chiluba (1991-2000). In contrast to the one party period in which the various Land Acts placed no economic value on land apart from the sale of improvements made on land, the 1995 Land Act did that (GRZ, 1995).

Thus, the study is organized as follows: Colonial Land Ordinances 1890-1964; 1964-1990 Land Acts; 1991-2000 Land Acts; and, Opportunities and challenges of the 1995 Land Act. In each segment, emphasis is laid on land holding rights to individuals and corporate bodies, and the resulting opportunities and challenges.

\subsection{Rationale, Focus and Scope}

The rationale of the current study was to establish the history, opportunities and challenges emerging from the 1995 Lands Act. The study focused on smallholder farmers who had been directly (or indirectly) affected in their areas by the general changing process of land administration. The smallholder farmers in Chibombo (also referred to as villagers) were targeted because they are the ones holding land mainly on customary basis. The 
areas focused on by the study were Chibombo and Katuba Farming Blocks in Chibombo district. Specifically, the areas around Chibombo and Mungule were identified as the two regions most affected by developments in the process of customary land administration. The study was limited to Chibombo district only and involved 60 smallholder farmers who were purposely sampled.

Furthermore and most importantly, the study, unlike other studies that had only looked at the issuance of title deeds to various stakeholders, added opportunities and challenges emerging from the 1995 Lands Act. The current study has revealed that between 1995 and 2005 few individuals and corporate bodies took advantage of the Act in Chibombo district. After 2005, however, fieldwork evidence shows that many individuals started to buy and convert traditional land to leasehold title. As a result, there emerged a mixture of opportunities and challenges, which are the focus of the current study. This study, hence, outlines some of the opportunities and challenges which emerged since the introduction of the Lands Act 1995, especially with regard to the welfare of the villagers for whom the Act was initially intended to benefit. As a resident of Chibombo district, the researcher was motivated to undertake this study because he felt there was need to document emerging trends in land administration and examine how the new Act had benefited (or not) the smallholder farmers.

\section{Materials and Methods Used for the Study}

\subsection{Location of the Study Area}

Zambia is located in the southern-central part of Africa between $8^{\circ}$ and $18^{\circ}$ south of the Equator, and between $14^{\circ}$ and $35^{\circ}$ east of the Prime Meridian and comprises 10 provinces (Figure 1). These are Central, Copperbelt, Eastern, Luapula, Lusaka, Northern, North-western, Southern, Muchinga and Western Province. Central Province is located between latitudes $12^{\circ} 4^{\prime}$ and $15^{\circ} 45^{\prime}$ South, longitudes $25^{\circ} 11^{\prime}$ and $31^{\circ} 30^{\prime}$ East (Table 1 , Figures 1 and 2); Chibombo district is located $14^{\circ} 40^{\prime}$ and $15^{\circ} 25^{\prime} \mathrm{S}$, and $27^{\circ} 10^{\prime}$ and $29^{\circ} 00^{\prime} \mathrm{E}$ (Table 1).

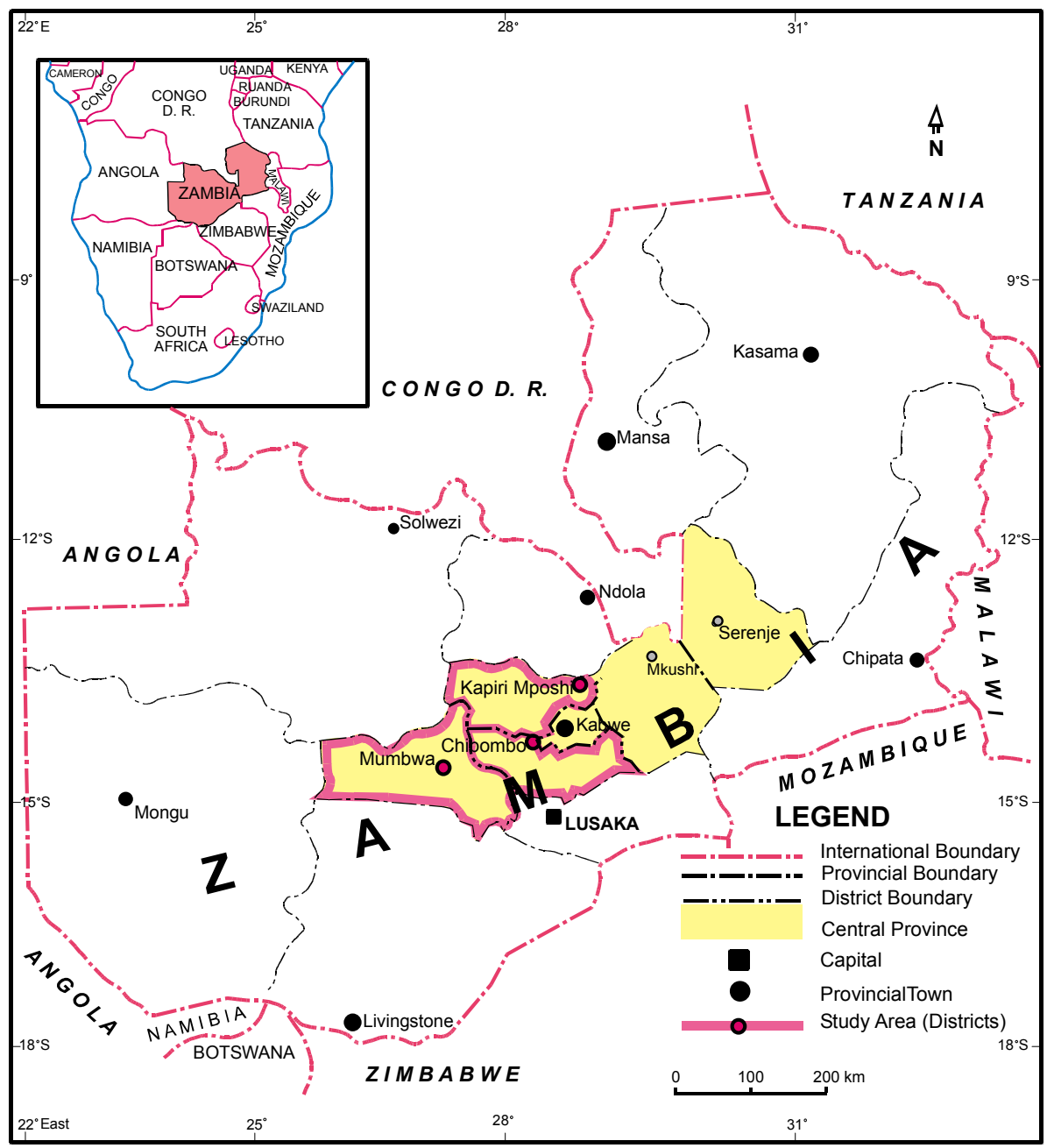

Figure 1. Location of study area-Chibombo, Central and Zambia 
Table 1. Summary of physical and socio-economic characteristics of the study area

\begin{tabular}{|c|c|c|c|c|c|}
\hline \multicolumn{2}{|c|}{ Characteristics } & \multicolumn{2}{|c|}{ Central Province } & \multicolumn{2}{|c|}{ Chibombo } \\
\hline \multirow[t]{2}{*}{ Location } & Latitude & $12^{\circ} 04^{\prime} \mathrm{S}$ & $15^{\circ} 45^{\prime} \mathrm{S}$ & $14^{\circ} 40^{\prime} \mathrm{S}$ & $15^{\circ} 25^{\prime} \mathrm{S}$ \\
\hline & Longitude & $25^{\circ} 11^{\prime} \mathrm{E}$ & $31^{\circ} 30^{\prime} \mathrm{E}$ & $27^{\circ} 10^{\prime} \mathrm{E}$ & $29^{\circ} 00^{\prime} \mathrm{E}$ \\
\hline \multicolumn{6}{|c|}{ Physical Features } \\
\hline \multicolumn{2}{|c|}{ Agro-ecological region } & Region B & \multicolumn{3}{|l|}{ Region B } \\
\hline \multicolumn{2}{|l|}{ Soils } & $\begin{array}{l}\text { well-drained } \\
\text { acrisol, } \\
\text { luvisol-Phaeozem } \\
\text { and arenosol soils }\end{array}$ & \multicolumn{3}{|c|}{$\begin{array}{l}\text { well-drained acrisol, luvisol-Phaeozem and } \\
\text { arenosol soils }\end{array}$} \\
\hline \multicolumn{2}{|l|}{ Vegetation } & $\begin{array}{l}\text { Open woodland } \\
\text { and savannah } \\
\text { grassland }\end{array}$ & \multicolumn{3}{|c|}{ open woodland and savannah grassland } \\
\hline \multirow{3}{*}{$\begin{array}{l}\text { Climate } \\
\text { (Tropical } \\
\text { savannah } \\
\text { climate) }\end{array}$} & Rain & & \multirow{2}{*}{\multicolumn{3}{|c|}{$\begin{array}{l}\text { Medium } \\
900-1200 \mathrm{~mm}\end{array}$}} \\
\hline & & & & & \\
\hline & Temp & Cool to hot & \multicolumn{3}{|l|}{ Cool to hot } \\
\hline \multicolumn{6}{|c|}{$\begin{array}{l}\text { Seasons: Cool } \\
\text { dry, hot dry, hot } \\
\text { wet seasons. }\end{array}$} \\
\hline \multicolumn{6}{|c|}{ Social-economic characteristics } \\
\hline \multirow[t]{4}{*}{ Roads } & Dust & Numerous & & Numerou & \\
\hline & Gravel & Numerous & & Numerou & \\
\hline & Tarred & Great North Road & & Great No & \\
\hline & & Great West Road( & usaka-Mongu) & $\begin{array}{l}\text { Great We } \\
\operatorname{Road}(\mathrm{Lu}\end{array}$ & ongu) \\
\hline \multirow[t]{2}{*}{ Rail } & & \multicolumn{2}{|c|}{ Livingstone-Copperbelt } & \multicolumn{2}{|c|}{ Livingstone-Copperbelt } \\
\hline & & Tanzania-Zambia & TAZARA) & & \\
\hline \multirow[t]{3}{*}{ Population } & Rural & \multicolumn{2}{|c|}{769,202} & \multicolumn{2}{|c|}{237,657} \\
\hline & Urban & \multicolumn{2}{|c|}{243,055} & \multicolumn{2}{|c|}{3,955} \\
\hline & Total & $1,012,257$ & & & \\
\hline \multirow[t]{9}{*}{$\begin{array}{l}\text { Livelihood } \\
\text { activities }\end{array}$} & $\begin{array}{l}\text { Rural } \\
\text { (only) }\end{array}$ & \multicolumn{2}{|c|}{$\begin{array}{l}\text { Farming-small scale \& } \\
\text { Commercial }\end{array}$} & \multicolumn{2}{|c|}{$\begin{array}{l}\text { Farming-small scale \& } \\
\text { Commercial }\end{array}$} \\
\hline & & \multicolumn{2}{|l|}{ Fishing } & \multicolumn{2}{|l|}{ Fishing } \\
\hline & & Lumbering & & Lumberir & \\
\hline & & Hunting & & & \\
\hline & & Mining & & & \\
\hline & & Education & & Educatiol & \\
\hline & & Health & & Health & \\
\hline & & Agro-processing & & Agro-pro & \\
\hline & & Agro-marketing & & Agro-ma & \\
\hline
\end{tabular}

Source: Bwalya et al. (1997); CSO (2003); GRZ [soil map], 1986; Meteorological Department, 2000.

NB: Region A: Low rainfall region; Region B: Medium rainfall; Region C: High rainfall. 


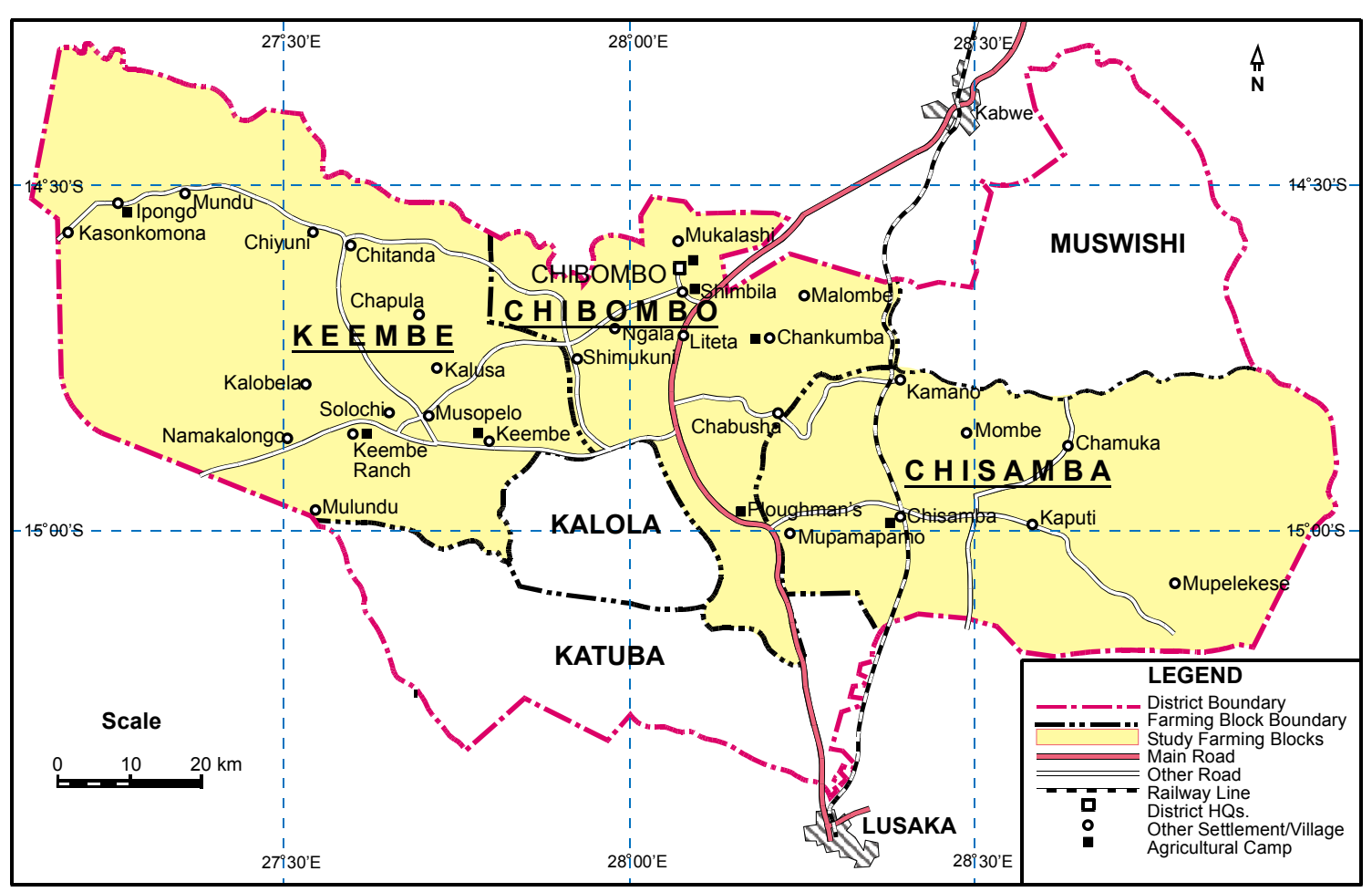

Figure 2. Farming blocks in Chibombo district

The current study focused on opportunities and challenges emanating from the conversion of customary land to title. The study used Chibombo district as case study because numerous customary lands had been converted to title, especially in areas such as Chibombo and Mungule areas of Chibombo district, since the enactment of the 1995 Lands Act which permitted customary land holders to convert to title after the introduction economic liberalization by the Movement for Multi-party Democracy (MMD) led by Dr. Frederick, J. T. Chiluba in 1991. The main purpose of such a dramatic legal inclusion, among others, was to empower smallholder farmers to have legal right to own their land, use such title as collateral in financial institutions and add economic value to land (Kajoba, 1998; Sichone, 2003). The 60 smallholder farmers sampled for this study were purposefully selected because there was evidence that they had been affected by the new process of land administration. Chibombo district was selected for this study because there existed evidence of customary land conversion to title and it was greatly affected by the influx of people from neighbouring towns seeking land for settlements, agriculture and other activities. The district was equally easily accessible to the researcher.

\subsection{Methods of Collecting Data}

\subsubsection{Types of Data}

\subsubsection{Secondary Data}

Secondary data about land administration in Zambia emanating from various Acts, including the 1995 Lands Act, and other pieces of legislation from elsewhere in the world was obtained from textbooks, journals, Acts and other documents at the University of Zambia, Nkrumah University, the Ministry of Lands and Natural Resources, and Chibombo district council.

\subsubsection{Primary Data}

Primary data about land administration in Zambia in general, and emerging opportunities and challenges from the 1995 Lands Act were obtained through questionnaires, interviews and observations in Chibombo district between 2008 and 2013. Questionnaires were distributed among 60 (sixty) purposely selected smallholder farmers in the district (39 and 21 smallholder farmers in Chibombo and Mungule respectively); while interviews were conducted among 21 (twenty-one) randomly selected smallholder farmers in Chibombo and Katuba farming blocks, the district agricultural coordinator (DACO), 3 (three) council officials, and 6 (six) community leaders (chief Liteta, and 5 village headmen). All government and community leaders were purposely sampled because of the type of information they held. Between 1995 and 2011 records of the type and specific details of 
title holders at the Chibombo district council were scanty and hence the reason why the study was extended to include 2012 and 2013.

\section{Results and Discussion}

\subsection{Land Laws and Land Tenure Categories in Zambia}

According to Adams (2003) land laws fall in two categories: modern customary land law originating from indigenous traditions of Zambians; and leasehold, emanating from English common law of the Commonwealth. Other laws which Zambia has had over land include: The Lands and Deeds Registry Act 1914; The Land Survey Act 1960; The Lands Acquisition Act 1970; Land (Conversion of Titles) Act 1975; Lands Act 1995; Constitution of Zambia. Historically, the evolution of land administration through various Acts and customs premised on the fact that "The European approach conceives of land as a property and hence respects individual property rights and, the African approach conceives of land as a common resource, therefore respecting collective use and management" (Wanyeki, 2003). The post independence Land Acts and administrative measures seem to have been oriented towards the European approach, disregarding the reality that customary land rights were flexible and responded to community needs and challenges at different historical times.

According to GRZ (2003); Kajoba (1998) and Sichone (2003), Zambia covers a total landmass of $75 \mathrm{~m}$ hectares divided as follows: State land comprises $4.5 \mathrm{~m}$ hectares (6\%), and Customary Land comprising the rest (94\%). Customary Land was formerly consisting of Reserve Land (27.2 m hectares (36.2\%) and Trust Land, $43.3 \mathrm{~m}$ hectares (57.7\%).

\subsection{Colonial Land Administration-Colonial Land Ordinances: 1890-1964}

Prior to the arrival of colonial administration around 1890, land in Zambia was administered according to customary law and varied between chiefdoms (Sichone, 2008). During colonial rule an English land tenure system was introduced in the territory. According to Kajoba (1998) and Sichone (2003) the colonialists introduced Crown land for white settlements and, Native Reserves and Trust lands for Africans. The power to alienate land was vested in the Governor (Sichone, 2003). The chronology of Land administration in Northern Rhodesia (present day Zambia) is provided in Table 2 below as follow:

\subsection{Post Independence Land Administration (1964-1990)}

\subsubsection{Land Administration: 1964-1973}

On attaining independence in 1964, Zambia inherited, from the Colonial administration, an English Land tenure system but made cosmetic changes by removing old titles to replace them with new ones deemed racially appropriate (GRZ, 1985; Kajoba, 1998; Sichone, 2003). Thus, Crown Land became State land, Native Reserves became Reserve land and Native Trust land became Trust land (Kajoba, 1998; Sichone, 2003). According to the Zambian government reforms were necessary because:

"Experience had demonstrated that policies of the previous administrations...were discriminatory in that (until about two years before independence) one had, in general, to have a white skin before one could acquire a piece of land on State Land and provided his skin was of a dark pigmentation his only resource was in the (Native) Reserves or (Native) Trust Lands, which were far from markets, badly served by communications and transport and in some areas infertile, tsetse fly infested and lacking in water. These polices were seen as an economic colour-bar of a subtle nature" (Legislative Council, 1930).

Through the Philosophy of Humanism the government enacted laws that established state control in all matters of land. This was done through reforms announced in the Mulungushi Economic Reforms of 1968 and included:
(a) All land should be vested in the President of the Republic of Zambia;
(b) All land under freehold should be converted to leasehold tenure for hundred years;
(c) Land under customary tenure not to be converted into leasehold, and
(d) Land reforms should be directed at improvement of the use of agricultural land. (Mvunga, 1977). 
Table 2. Land administration in Northern Rhodesia: pre-colonial period to 1964

\begin{tabular}{|c|c|c|c|}
\hline YEAR & Land administration & Power of land alienation & Title deeds \\
\hline $\begin{array}{l}\text { Pre-colonial } \\
\text { period }\end{array}$ & $\begin{array}{l}\text { Customary land administration by } \\
\text { chiefs }\end{array}$ & Individual chiefs & Non \\
\hline 1884 & $\begin{array}{l}\text { Treaty- British South African } \\
\text { Company (BSA) and Barotseland } \\
\text { under Chief Lewanika }\end{array}$ & $\begin{array}{l}\text { Individual chiefs e.g. } \\
\text { Lewanika of Lozi people }\end{array}$ & Non \\
\hline 1890 & $\begin{array}{l}\text { BSA Company grants African rights to } \\
\text { large areas of tribal land in exchange } \\
\text { for mineral concessions through the } \\
\text { Lochner Concession }\end{array}$ & BSA Company and chiefs & $\begin{array}{l}\text { Title deeds in BSA } \\
\text { controlled areas }\end{array}$ \\
\hline 1911 & $\begin{array}{l}\text { Northern Rhodesia Order in Council } \\
\text { orders BSA company to assign more } \\
\text { land for use and occupation by } \\
\text { Africans and, } 1,500 \text { whites settle in } \\
\text { Northern Rhodesia as missionaries, } \\
\text { miners, and traders }\end{array}$ & BSA Company & Title deeds in settler areas \\
\hline 1919 & $\begin{array}{l}250 \text { white farmers settle in Northern } \\
\text { Rhodesia }\end{array}$ & BSA Company & Title deeds in settler areas \\
\hline 1924 & $\begin{array}{l}\text { BSA hands over territorial } \\
\text { administration to British government } \\
\text { who appoints a Governor }\end{array}$ & $\begin{array}{l}\text { Governor of Northern } \\
\text { Rhodesia }\end{array}$ & Title deeds in settler areas \\
\hline $1926-1928$ & $\begin{array}{l}\text { Series of Native Reserve } \\
\text { Commissions regularize white } \\
\text { settlements and African Reserves; } \\
\text { unclassified land established for } \\
\text { expected white settlers }\end{array}$ & $\begin{array}{l}\text { Governor of Northern } \\
\text { Rhodesia }\end{array}$ & Title deeds in settler areas \\
\hline 1928 & $\begin{array}{l}\text { Northern Rhodesia Order in Council } \\
\text { establishes Crown Land for whites } \\
\text { under English Law; Reserves for } \\
\text { African occupation under customary } \\
\text { tenure arrangements }\end{array}$ & $\begin{array}{l}\text { Governor of Northern } \\
\text { Rhodesia }\end{array}$ & $\begin{array}{l}\text { Title deeds in Crown } \\
\text { lands }\end{array}$ \\
\hline 1930 & Long leases given to white settlers & $\begin{array}{l}\text { Governor of Northern } \\
\text { Rhodesia }\end{array}$ & $\begin{array}{l}\text { Title deeds in Crown } \\
\text { lands }\end{array}$ \\
\hline 1938 & $\begin{array}{l}\text { Pimm Commission set up to look at } \\
\text { complaints about land overcrowding } \\
\text { in African reserves }\end{array}$ & $\begin{array}{l}\text { Governor of Northern } \\
\text { Rhodesia }\end{array}$ & Title deeds in settler areas \\
\hline 1947 & $\begin{array}{l}\text { Northern Rhodesia (Native Trust } \\
\text { Land) Order in Council recommends } \\
\text { reversal of Native Reserve land policy } \\
\text { and permitting native African } \\
\text { occupation of some Crown Land(100 } \\
\text { m acres) }\end{array}$ & $\begin{array}{l}\text { Governor of Northern } \\
\text { Rhodesia }\end{array}$ & $\begin{array}{l}\text { Title deeds in Crown } \\
\text { areas }\end{array}$ \\
\hline 1950 & $\begin{array}{l}\text { Crown Land shrinks to } 4.6 \mathrm{~m} \text { acres } \\
\text { while African Reserve and Reserve } \\
\text { Trust Land increase to } 171 \mathrm{~m} \text { acres }\end{array}$ & $\begin{array}{l}\text { Governor of Northern } \\
\text { Rhodesia }\end{array}$ & $\begin{array}{l}\text { Title deeds in Crown } \\
\text { areas }\end{array}$ \\
\hline 1960 & $\begin{array}{l}\text { Over } 1,000 \text { white farms established in } \\
\text { Northern Rhodesia }\end{array}$ & Governor of Northern & $\begin{array}{l}\text { Title deeds in Crown } \\
\text { areas }\end{array}$ \\
\hline 1964 & $\begin{array}{l}\text { Crown Land converts to State Land; } \\
\text { Native Reserves to Reserves; Native } \\
\text { Trust Land to Trust Land }\end{array}$ & $\begin{array}{l}\text { President of Republic of } \\
\text { Zambia }\end{array}$ & Title deeds in State lands \\
\hline
\end{tabular}

Source: Roth et al. (2003). 
Out of such thinking came out the Johnson Lands Commission with three main terms of reference. Thus, "(a) to examine all aspects of land policy and administration which were inherited on independence, (b) to examine the land problems submitted by the Provincial Working Committees, and (c) to submit recommendations to the Cabinet on the future land policy and land laws of Zambia" (Sichone, 2003). The Johnson Commission recommended that "(i) that Orders-in-Council should be revoked and the new Act should only provide for only two categories of land, viz: State Land and Customary Land, (ii) that customary land be brought under the provisions of the Land Administration Act relating to the acquisition of land rights as soon as reasonably practicable" (Sichone, 2003). For various reasons the recommendations of the Johnson Commission were not implemented but instead the government announced specific land reforms in the Mulungushi Economic Reforms of 1968 as follows:

"(a) all land should be vested in the President of the Republic of Zambia, (b) all land under freehold should be converted to leasehold tenure for hundred years, (c) land under customary tenure not be converted into leasehold, and (d) land reforms should be directed at improvement of the use of agricultural land" (GRZ, 1968). These reforms were done on a socialist line placing man as center without placing value on land. It was such thinking of government which later had a bearing on all Land Acts during the 1968 to 1990 period.

Government went ahead to institute reforms on land administration despite "The Zambia (State Lands and Native Reserves) Order 1964; the Zambia (Trust Land) Order 1964 and the Zambia (Gwembe District) Order 1964, all had the provision that "any estate, right or interest in or over any land or immovable property which the governor of Northern Rhodesia prior to independence created, granted, recognized or otherwise acknowledged should continue to have the same validity as they had before independence" (Kajoba, 1998). To consolidate their position, government passed the 1970 Lands Acquisition Act which stated in part that "... the President may, whenever he is of the opinion that it is desirable or expedient in the interest of the Republic so to do, compulsorily acquire any property of any description" take over private property, but the Act provided for compensation to be paid for such property in cash or kind (where a grant of State land not exceeding in value, the value of the land acquired was given in lieu" (GRZ, 1970: 6-7).

\subsubsection{Land Administration: 1973-1990}

Arising from the 1968 Mulungushi reforms and the Land Conversion of Title Act, 1975, which stated, among others, that "every piece or parcel of land which immediately before the commencement of this Act was vested in or held by any person-(a) absolutely, or as a freehold ... or in any other manner implying absolute rights in perpetuity; or (b) as a leasehold extending beyond the expiration of one hundred years from the commencement of this Act; is hereby converted to a statutory leasehold and shall be deemed to have been so converted with effect from the first day of July, 1975" (GRZ, 1975). Scholars such as Mvunga (1982) have stated in part the "... seizure by the state of all unutilized land which was held by commercial farmers; abolition of the sale of vacant land; the closure of all real estate agencies; ...'(Mvunga, 1982). Furthermore, it was this Act which led to land having no market value although individuals could sell improvements on it. The landscape of leases in the 1970s was as follows (Table 3):

Table 3. Leases of State Land by type of lessee, late 1970s

\begin{tabular}{lcccc}
\hline Lessee & $\begin{array}{c}\text { Number of } \\
\text { leases }\end{array}$ & $\begin{array}{c}\text { Total area } \\
\text { leased }\end{array}$ & $\begin{array}{c}\text { Percent of area } \\
\text { leased }\end{array}$ & $\begin{array}{c}\text { Average size of } \\
\text { household (ha) }\end{array}$ \\
\hline & $\mathrm{A}$ & $\mathrm{B}$ & $\mathrm{C}$ & $\mathrm{B} / \mathrm{A}$ \\
Private & 1,674 & $1,232,987$ & 60.4 & 737 \\
Government & 502 & 541,902 & 26.5 & 1,079 \\
Settlement schemes & 61 & 62,241 & 3.1 & 1,020 \\
Cooperatives & 10 & 6,580 & 0.3 & 658 \\
Religious/educational & 69 & 45,677 & 2.2 & 662 \\
Vacant & 74 & 44,387 & 2.2 & 600 \\
Nonagricultural & 228 & 107,500 & 5.3 & 471 \\
Total & $\mathbf{2 , 6 1 8}$ & $\mathbf{2 , 0 4 1 , 2 7 4}$ & $\mathbf{1 0 0 . 0}$ & $\mathbf{7 8 0}$ \\
\hline
\end{tabular}

Source: Bruce and Dorner, Agricultural Land Tenure in Zambia: Perspectives, Problems and Opportunities, LTC Research Paper no. 76 (Madison: Land Tenure Center, University of Wisconsin, 1982, p. 11, in Roth, M et al., 2003). 


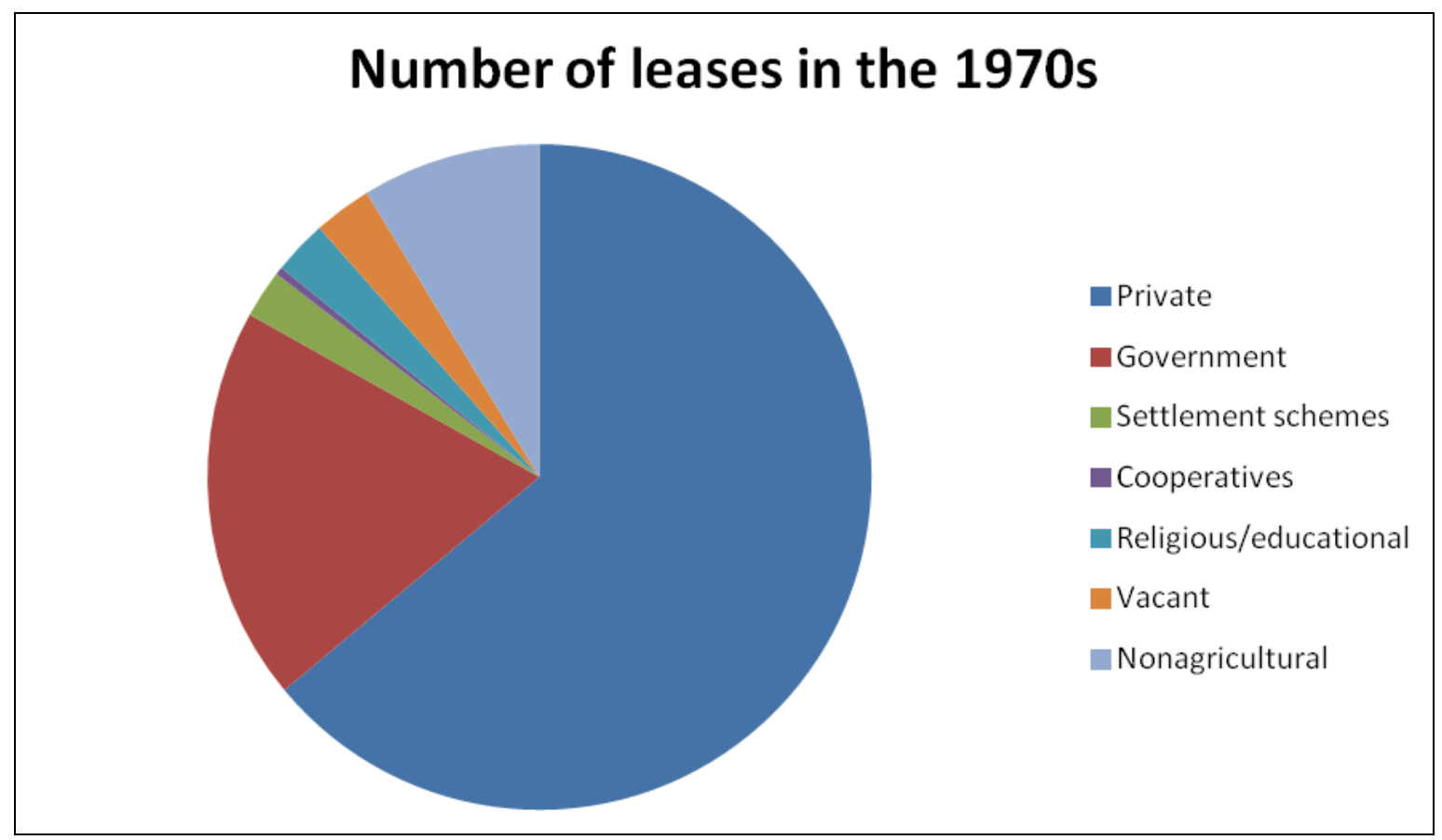

Figure 3. Number of leases in the 1970s

It is clear from the foregoing information in Table 3 and Figure 3 above that the majority of leases were in private hands $(60.4 \%)$. Government and government-related organizations (settlement schemes, cooperatives and religious/educational organizations) made up $32.1 \%$ of leases. To a large extent one would conclude that such a landscape existed because the white settler farmers were still in the country and, government had started to take up a large share of agricultural land based on the Mulungushi Reforms in line with the philosophy of Humanism.

In terms of land tenure classification in Zambia after government made the Mulungushi Reforms of 1968 and, the 1975 Land Conversion of Titles Act, the following statistics for 1973 and 1987 are given in Table 4.

Table 4. Land tenure classification, Zambia, 1973 and 1987 (million hectares)

\begin{tabular}{lcc}
\hline Land classification & $\mathbf{1 9 7 3}$ & $\mathbf{1 9 8 7}$ \\
\hline State (formerly Crown) Land & $4,080,647$ & $4,518,953$ \\
Freehold & $1,015,791$ & \\
Leasehold & $1,284,788$ & \\
Land under tribal occupation & 509,396 & \\
Unalienated land & 125,102 & \\
Inundated by water & 216,250 & \\
Forest reserves & 546,570 & \\
Protected forest reserves & 382,750 & \\
Reserves & $27,314,000$ & $27,297,500$ \\
Trust Land & $38,977,530$ & $43,447,900$ \\
National parks and wildlife areas & $5,826,300$ & \\
Total & $\mathbf{7 6 , 1 9 8 , 4 7 7}$ & $\mathbf{7 5 , 2 6 4 , 3 5 3}$ \\
\hline
\end{tabular}

Source: Roth, M et al. (2003).

By 1987 land under customary control (Reserves and Trust lands) made 94\% of the total land for agriculture and state land was only 6\%. According to Kajoba (1998), Sichone (2003) and others, legal provision of obtaining title deeds on customary land was first made in 1985 by the Kenneth Kaunda UNIP government. 
At the individual level the following picture of issuance of title deeds existed between 01/11/85 and 31/10/91 (Table 5).

Table 5. Offers of title Deeds issued between 01/11/85 to 31/10/91

\begin{tabular}{lcccc}
\hline Province & Male & Female & Others & Total \\
\hline Central & 20 & 3 & 630 & 653 \\
Copperbelt & 47 & 8 & 1,302 & 1,357 \\
Eastern & 8 & 0 & 392 & 400 \\
Luapula & 12 & 0 & 194 & 206 \\
Lusaka & 17 & 4 & 1,437 & 1,458 \\
Northern & 6 & 0 & 300 & 306 \\
North-western & 3 & 0 & 123 & 126 \\
Southern & 26 & 4 & 665 & 695 \\
Western & 6 & 3 & 352 & 361 \\
Total & $\mathbf{1 4 5}(\mathbf{2 . 6 \% )}$ & $\mathbf{2 2}(\mathbf{0 . 4} \%)$ & $\mathbf{5 , 3 9 8}(\mathbf{9 7 \%})$ & $\mathbf{5 , 5 6 5}$ \\
\hline
\end{tabular}

Source: Kajoba, 1998.

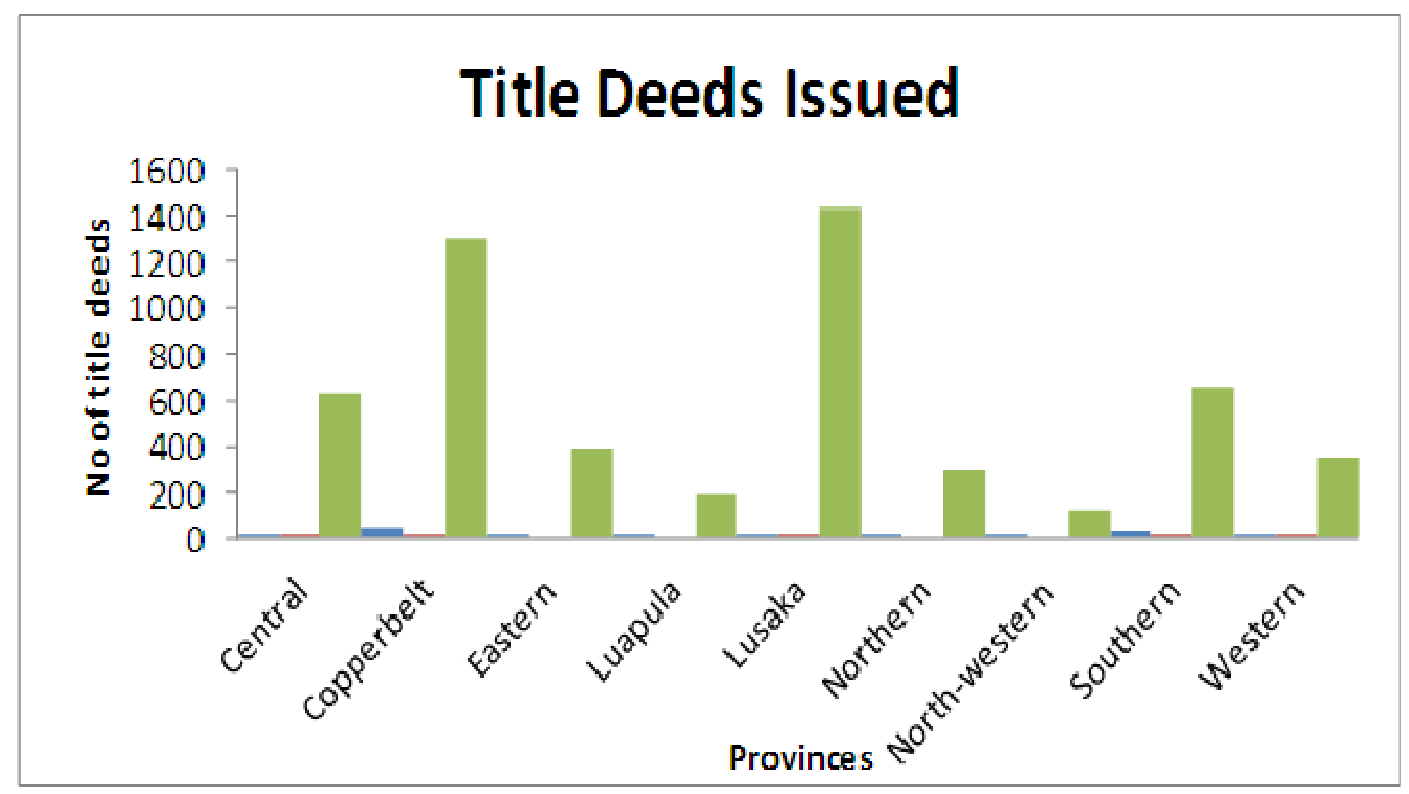

Figure 4. Offers of title deeds issued between $01 / 11 / 85$ to $31 / 10 / 91$

On the national level, Table 5 and Figure 4 indicate that there were more title deeds issued to "others" (companies, parastatals, charitable organizations, etc) than to individual men $(2.6 \%)$ and women $(0.4 \%)$. To a large extent, this picture of $3 \%$ individuals to $97 \%$ organizations reflected the tone and gravity of government policy which discouraged individuals from amassing wealth since it was against the philosophy of Humanism that was being vigorously pursued by the UNIP government of President David K. Kaunda. This is in line with the argument given by Bruce and Dorner who have stated that the "philosophy of Humanism as enunciated by the government of Zambia forecloses certain tenurial options. An example is freehold, while leasehold appears to be acceptable" (Bruce \& Dorner, 1982).

\subsubsection{Land Administration After 1991}

\subsubsection{General Introduction for Converting Customary Land to Title}

Therefore, in order to improve its productivity and empower villagers, the Zambian government passed an Act in 
1995 called the Lands Act, 1995. This Act, among others, provides for conversion of land holding from customary to leasehold tenure by authorizing chiefs to recommend to the government the issuance of a leasehold title to an individual man or woman or corporate body (GRZ, 1996; Kajoba, 1998; Sichone, 2003). It was the intention of government to permit smallholder farmers to have leasehold title to their pieces of land which they could offer as collateral for cash or commodity loans from financial institutions or any other lender (MMD MANIFESTO, 1996). In turn this would help to improve their individual capital outlay, and by extension their land productivity.

\subsubsection{Legal Procedure of Converting Customary Land to Title}

Sichone (2003) states that "The right to convert customary tenure to leasehold was first introduced by the colonial administration through the Reserves and Trust Land (adjudication of titles) Ordinance of 1962. This Ordinance contained the grant of normal titles over land held under customary law; however, it was never used as there was no demand to do so at the time. The UNIP government under Dr. Kenneth Kaunda re-introduced this provision in 1985 but was not again used as rampantly as it became after the 1995 Lands Act. The 1995 Lands Act, however, re-introduced a provision for the conversion of land held under customary tenure to leasehold tenure. Thus, the law provides that- a person who has a right to the use and occupation of land under customary tenure; or using and occupying land in a customary area with the intention of settling there for a period of not less than five years; may apply, to the Chief of the area where the land is situated for the conversion of such holding into a leasehold tenure" (Sichone, 2003). The 1995 Lands Act states in part that "Transfer of land from customary to statutory land can only take place after the approval of the chief, the Local Council, and (if the land is in a Game Management Area) the Director of the National Parks and Wildlife Service. An exact plan of the land to be converted needs to be created" (GRZ, 1995).

The procedure is that a person with an intention to use or occupy the land for a considerable time should apply in writing to the chief in his area through the headman stating his intention to convert the said land to leasehold. On receipt of the application, the chief will refuse or consent. If the application is consented to, the chief forwards the application and approval form to the Council in whose area the land to be converted is situated. The applicant is, thereafter, requested to appear before a full Council meeting. The purpose of such appearance is to establish the actual developmental plans of the applicant and, know whether or not there are conflicts about the land with the neighbouring residents in the area where the land is situated, and that there is no conflict between the customary law of the area and the 1995 Lands Act. Once approval is granted by the Council, the application is forwarded to the Ministry of Lands through the Provincial Lands office in the respective region for the final issuance of the leasehold title.

\subsubsection{Offers of Title Deeds Between 01/11/91 to 03/11/1997}

After the introduction of economic liberalization in Zambia in 1991, government policy as alluded to earlier, shifted towards empowering individuals in line with the MMD manifesto (MMD, 1997). In order to achieve this goal, government implemented a number of steps. Among these were the 1993 National Conference on Land Policy and Legal Reform in the Third Republic (which recommended that only customary and leasehold tenure be the two categories of tenure in the country) and the eventual enactment of the 1995 Lands Act. As stated before, this Act permitted conversion of customary land to leasehold tenure on the recommendation of respective chiefs where the land is located. Generally, after the introduction of the new Act a shift from institutional to individual title deed empowerment occurred as shown in Table 6 below.

From the above statistics (in Table 6 and Figure 5) it is clear that many men (66.4\%) and women (14.6\%) received leasehold title deeds for their pieces of land (Kajoba, 1997, 1998). Generally in fact, more individuals (80.4\%) received title deeds after 1991 than "others" (19.6\%). The term "others" refers to parastatals, non governmental organizations and companies, who apparently formed the majority of title holders before 1991 (97\%). Definitely, the reduction from $97 \%$ to $19.6 \%$ of corporate bodies receiving title deeds after 1991 is a tremendous shift. This needs to be measured against a rise in individual title issuance to $80.4 \%$ after 1991, which previously lay at $3 \%$. Up to this extent alone, one concludes that the 1995 Lands Act achieved its objective of empowering individuals to own land under title. However, this study established that there were more individuals from urban centers (over 90\%) obtaining title deeds on customary land than local smallholder farmers. Thus, the records at Chibombo district Council offices for 2013 for April and July reveal the following picture (Table 7). 
Table 6. Offers of title deeds between 01/11/91 and 03/11/97

\begin{tabular}{|c|c|c|c|c|}
\hline PROVINCE & MALE & FEMALE & OTHERS & TOTAL \\
\hline Central & 1,889 & 296 & 352 & 2,537 \\
\hline Copperbelt & 3,741 & 655 & 1,839 & 6,235 \\
\hline Eastern & 1,620 & 215 & 209 & 2,044 \\
\hline Luapula & 578 & 71 & 183 & 832 \\
\hline Lusaka & 6,860 & 2114 & 2,072 & 11,046 \\
\hline Northern & 923 & 106 & 160 & 1,189 \\
\hline North Western & 546 & 76 & 125 & 747 \\
\hline Southern & 1,549 & 192 & 320 & 2,061 \\
\hline Western & 945 & 218 & 253 & 1,416 \\
\hline Total & $18,651(66.4 \%)$ & $3,943(14.0 \%)$ & $5,513(19.6 \%)$ & 28,107 \\
\hline
\end{tabular}

Source: Kajoba, 1998.

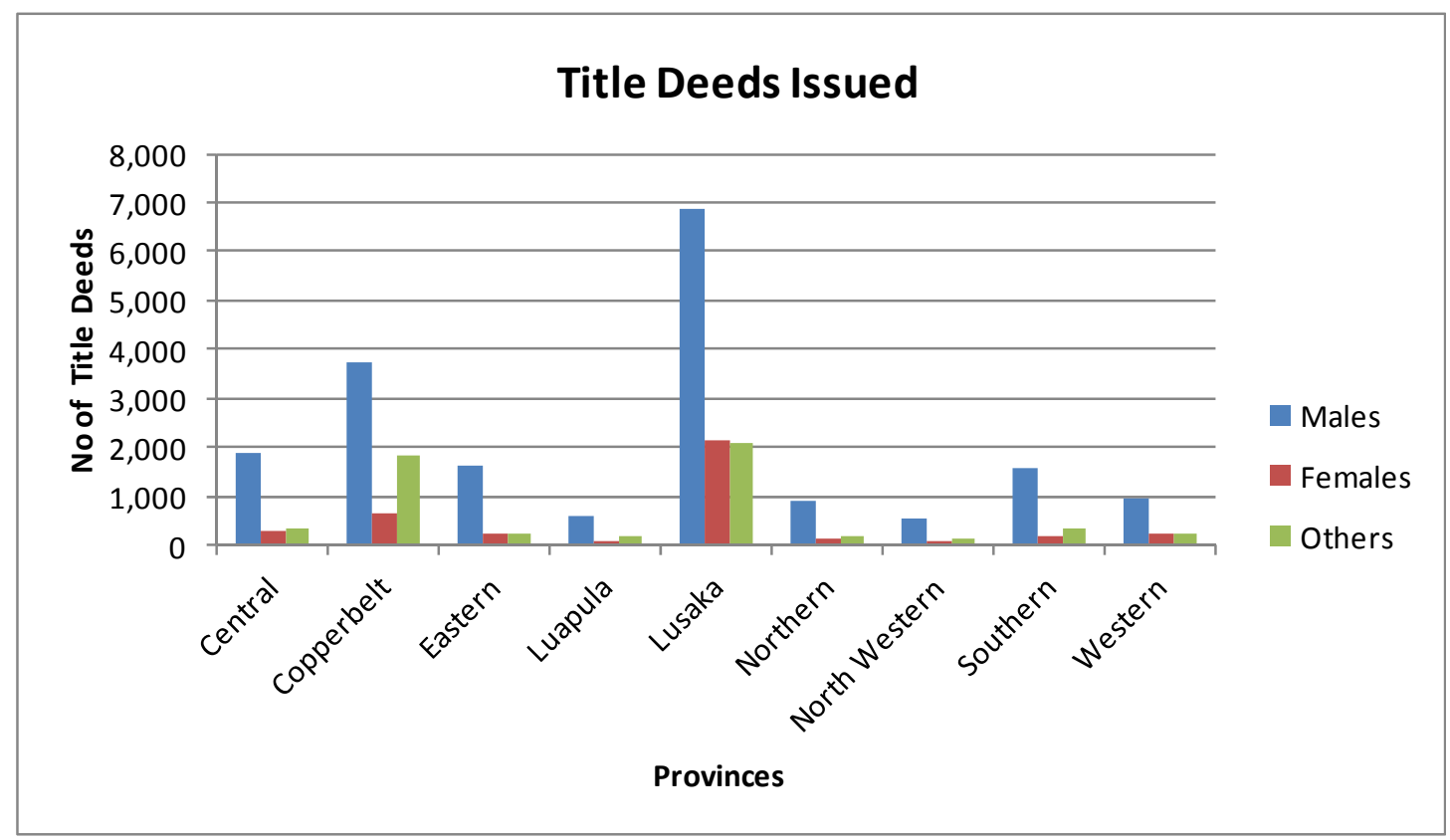

Figure 5. Offers of title deeds between 01/11/91 and 03/11/97

Table 7. Records of issued title deeds on customary land in chibombo district for April and July, 2013

\begin{tabular}{lccccccc}
\hline Month & \multicolumn{3}{c}{ MALE } & \multicolumn{3}{c}{ FEMALE } & TOTAL \\
\cline { 2 - 6 } & $\begin{array}{c}\text { Title deeds } \\
\text { issued }\end{array}$ & $\begin{array}{c}\text { Rural } \\
\text { address } \\
\%\end{array}$ & $\begin{array}{c}\text { Urban } \\
\text { address } \\
\%\end{array}$ & $\begin{array}{c}\text { Title deeds } \\
\text { issued }\end{array}$ & $\begin{array}{c}\text { Rural } \\
\text { address }\end{array}$ & $\begin{array}{c}\text { Urban } \\
\text { address }\end{array}$ & \\
& & $\%$ & & $\%$ & $\%$ & \\
\hline April & $58(65.9 \%)$ & $\mathbf{1}$ & $\mathbf{9 9}$ & $30(34.1 \%)$ & $\mathbf{0}$ & $\mathbf{1 0 0}$ & 88 \\
July & $94(71.8 \%)$ & $\mathbf{3}$ & $\mathbf{9 7}$ & $37(28.2 \%)$ & $\mathbf{1}$ & $\mathbf{9 9}$ & 131 \\
Total & $\mathbf{1 5 2}$ & & & $\mathbf{6 7}$ & & & $\mathbf{2 1 9}$ \\
& $\mathbf{( 6 9 . 4 \% )}$ & & & $\mathbf{( 3 0 . 6 \% )}$ & & & $\mathbf{( 1 0 0 \% )}$ \\
\hline
\end{tabular}

Source: Chibombo District Council, September, 2013. 
Looking at Table 7, it is evident that (1) more men than women have obtained title deeds to their land; (2) more urbanites than rural dwellers have obtained title deeds. Earlier studies done by scholars such as Kajoba (1998) have confirmed the assertion that more men have received title deeds than women; while Tor and Christian confirmed an urban land purchase dominance in southern Mali in which they have stated that "Urban elites represent the biggest land-buying group" (Tor \& Christian, 2002). These statistics are largely in agreement with the researcher's findings in Chibombo and Mungule areas of Chibombo district in which out of the 60 surveyed smallholder farmers whose pieces of land had been affected by the process of conversion of customary land to leasehold, $53(88.3 \%)$ were from urban areas, with only 7 (11.7\%) being local. Of the $88.3 \%$ urban individuals $41(77 \%)$ were from Lusaka City alone. The dominance of Lusaka over other towns could be, among others, due to the level of affluence of the people in the city and proximity to the affected areas.

The high percentage of individuals from other places may be attributed to a number of reasons. Some reasons given by key informants during fieldwork indicate the following: (1) most smallholder farmers do not have the same resource base as their urban counterparts; (2) most smallholder farmers do not have the same level of education as their urban counterparts; (3) urban dwellers have better access to information than rural dwellers; (4) urban dwellers seem to value the concept of private property against most rural dwellers who are content with communal and family property ownership rights passed from one generation to another; (5) urban dwellers seem to have a better understanding of the process of customary land conversion to leasehold.

Arising from these assumptions, it can be argued that the 1995 Lands Act seem to have succeeded in empowering individuals to have title to land than corporate bodies, more affluent individuals (over 90\%) benefitted from the Act while only about 5\% smallholder farmers did so. Additionally, the trend of men having an upper hand over women in matters of land continued even after the introduction of this Act. No informant gave the researcher any evidence of using the titled customary land as collateral for loans.

Another line of argument is that regionally there emerged a pattern in which people along already developed areas such as near towns, along the rail line and main roads were the ones benefitting from the scheme of title deeds than those in more remote areas. In support of this line of thought Kajoba argues that:

"Regionally, the line of rail provinces such as Lusaka and the Copperbelt continue to attract more offers. But it is interesting to note that although in percentage terms the trends are about the same for Western Province during the UNIP (6.5\%) and MMD (5.5\%) rule respectively, there is an appreciable absolute increase in offers, despite the fact that traditional authority tends to be much stronger here rather than perhaps elsewhere in rural Zambia, given the history of the region as a 'protectorate' since the colonial times." (Kajoba, 1998).

\section{Global Situation}

Changes in land administration, especially with regard to customary land, are not unique to Zambia alone. Kajoba states that "Land reform in many developing countries has attempted to ensure that smallholder farmers get access to land, water and other natural resources ... (Kajoba, 2003). Kajoba further states that "In Latin America, land reform especially since the 1950s has dealt with the complex issue of how to redistribute land from the powerful landlords to the peasants in the hacienda system, often referred to as Latifundio/Minifunido complex" (Kajoba, 2003).

In Sub-Saharan Africa, land reform debate is mainly concerned with the need to harmonize traditional communal tenure with modern individualized tenure in order to create an enabling environment for agricultural transformation and sustainable development (Kajoba, 2003). It is contended by scholars such as Chinene et al. (1998) that there is a general agreement that traditional land tenure rules in Sub-Saharan Africa do not provide the necessary enabling environment for agricultural development because land rights are not registered, and are thus not sufficiently secure for long term investment. For instance, Tor states that "... agricultural land in peri-urban areas of the Malian cotton zone is converted, at a remarkable pace, from inalienable customary tenure to various forms of exclusive and alienable holdings" (Tor, 2002). With regard to land sale transactions in rural Francophone Africa, Delville (2003) says that ..." the development of market transactions in land does raise the question of norms and procedures able to regulate them, in a context where such sales are often discreet, if not entirely hidden, and usually not explicitly acknowledged as normal practice ... and that the use of 'pieces of paper', in some form or another, is common and sometimes almost systematic in respect of 'sales' and other 'transfers', whether or not public officials are called upon to validate the contracts." (Delville, 2003). In other parts of Africa such as Zambia and Tanzania, "An increasing number of particularly urban people try to obtain access to land ... when formally sanctioned by an officially approved title deed, but more informal written evidence, signed by representatives for the official or traditional village authorities and witnesses, is becoming commonplace ..." (Odgaard, 2003). 
On Tanzania, Odgaard (2003) says ...”there is now an increasing tendency for many people to double safeguard their land rights, that is, on the one hand attempting to have customary rights 'formalized' and, on the other, to have 'modern' rights legitimized, that is sanctioned by custom" (Odgaard, 2003).

When selling a parcel of land or part of it, for purposes of obtaining money for processing a title deed or for any other reason, farmers and traditional leaders are both involved. Tor and Christian have said "... descendants of the first family to settle in an area, land chiefs are the biggest landholders and consequently the most important sellers of land. It is not only land chiefs who have started to sell land, but also farmers in general who feel that they have some land to spare. Sometimes land is sold where there is a conflict over who is the rightful owner. Farmers are rarely buyers ... Urban elites represent the biggest land-buying group" (Tor \& Christian, 2002).

From the preceding information above, it is apparent that selling and conversion of customary land to title is taking place in different parts of Africa and elsewhere. In order for traditional land to obtain title it may first have to be sold to another person (s) or where the land holder has enough resources obtain authorization to convert on their own.

\subsection{Opportunities Emerging From Converting Customary Land to Leasehold Title}

On a scale of 1 to 5 ( 1 being the lowest and 5 the highest score), when informants were asked to give reasons why they sold land, they gave money as the main reason scoring 5 on the scale among villagers, Ministry of Agriculture and Cooperatives officials, while the chief and headmen gave development as the highest score. However, when the researcher asked Chief Liteta of Chibombo District why they encouraged those converting customary land to Leasehold tenure to pay USA $\$ 200$ (Kr1000 Zambian Kwacha) per hectare, money again scored 5 on the scale. This confirmed the response from villagers and Ministry of Agriculture and Cooperatives officials. The money obtained through the sell of part of their pieces of land benefitted smallholder farmers in various ways. These benefits are discussed below.

Between 5 and $10 \%$ of respondents stated that they sold part of their customary land in order to raise money to meet the various expenses involved in processing the acquisition of leasehold title through the chief to the government. The researcher found actual evidence that about $5 \%$ of such individuals had managed to achieve this goal. This situation was found true in Chibombo and Mungule areas of Chibombo district.

Over $80 \%$ of respondents among sellers of part of customary land said they used their money to build new housing units of either burnt clay bricks or concrete blocks with iron sheets. Slightly above $41 \%$ of respondents indicated that they had managed to purchase solar panels and batteries, Chinese hand lights, radios or small televisions. About $87 \%$ of smallholder farmers of ages between 20 and 50 used part of money from the sell of part of their customary land to buy cell phones. Kajoba (1994) reports similar developments among small-scale farmers in Chinena village of Chibombo District whose household income was improving through commercialization of their farming activities.

About $18 \%$ of people surveyed reported that they had bought some cattle or goats. Slightly above $56 \%$ said that they had used the money obtained from the sale of land to buy chemical fertilizers and seed. About $5 \%$ reported to have used the money to start a new business. Interestingly, $3 \%$ of male respondents stated that they used their money to marry extra wives. This trend was common among Tonga and Lenje speaking men who believed that improvements in wealth also meant increasing the number of wives as part of their polygamous culture. These statistics were supported by district council officials interviewed in all the three study areas. Less than $10 \%$ of respondents used their money to pay for conversion of their customary land to leasehold. Although this percentage is relatively low, it is definitely a positive development since it was a new trend which did not exist before.

Generally, the researcher found evidence of improvements in the quality of housing units and other new acquisitions among villagers. But, very limited evidence existed to support the argument that crop production had improved among smallholder farmers who had reduced their land hectarage after the sale of land for purposes of earning money to help them convert customary land to leasehold or for any other reason. In Katuba and Mungule areas of Chibombo district, it was observed that a cooking oil factory, some filling stations and guest houses/lodges had set up providing employment to the local villagers, thereby improving their financial resource base. The provision of employment to local people had an effect of improving the income level of smallholder farmers and their families. By extension, this had a ripple effect of improving the quality of life of the local people. 


\subsection{Challenges Emerging From Converting Customary Land to Leasehold Title}

In all the areas surveyed, the most notable challenge emerging from the introduction of the 1995 Lands Act was a marked reduction in the size of land they owned. None of the interviewed individuals provided evidence to the contrary. This trend was consistent with similar developments in other parts of the world where land ownership was being restructured (World Bank, 1994). In Liteta, Mungule and Chibombo areas of Chibombo district over $88 \%$ of individuals who sold part of the land reduced their land holding to less than $50 \%$ of their previous land size. Such a development had brought about overcrowding in places, a shortage of grazing land, land conflicts between local people and new owners who had introduced restrictions on stock and people movements and an eventual decline in crop production. For instance, two cases were reported in Chibombo where beacons were removed by local people who felt the new owners had taken their land.

Furthermore, due to the appetite for cash, one headman in Mungule area sold off his entire parcel of land because he said he wanted to migrate to Lusaka where he would be taken care of by his children, while another headman in Chibombo sold his land and houses to a pastor from one of the churches because he wanted to relocate into the interior of the chiefdom. A third case involved a senior headman in Chibombo Farming Block who now lives on Chibombo council land of about 5 acres because all his village land has been sold to other people that have since obtained leasehold title. While these may be perceived to be cases in the minority, they indicate an emerging trend which scholars and other stakeholders need to pay attention to.

Furthermore, a leadership wrangle is reported to have emerged among members of the Liteta royal family because chief Liteta is said to have sold part of Lukanga swamps in Chibombo district, which is a popular communal grazing area for cattle especially during the drier periods of the year. Such leadership wrangles are undermining the authority of village headmen and chiefs. Nevertheless, one may equally argue that if part of the Lukanga Swamp is given up to some private investor, the remaining portion which is under communal ownership may cause the local people to find other effective ways to utilize it without causing undue environmental pressure resulting from overgrazing. Better and more effective management of the remaining communal portion of the grazing land may lead to better resource use.

In Chibombo district, over $60 \%$ (Table 7 above) of new owners of land on title were people from other areas. Interestingly, among the buyers of traditional land, even in remote areas such as Ipongo farming block in Chibombo district, were Chinese, Indian and Lebanese businessmen from nearby towns like Lusaka. Tor and Christian (2002) noted a similar trend in Mali. In Kanwankuku area of Chibombo district a large piece of land which was once used as a camping site for Seventh Day Adventist Church members was reported to have been bought by an affluent businessman from one of the nearby towns, hence denying church goers of access to the land which they had used for many years previously.

Arguably, it may be added that the introduction of leasehold title on customary land may, in the long term, lead to an evolution in cultural and traditional practices of local people since new values, belief systems and ways of doing things will become a normal way of living because of the concept of private property. Mathieu et al have said the "...social evolutions over the last 30 years have ...weakened the degree of collective control the land chief and the lineage elders exercise over the way land is managed in the village. As a result, there has been a shift in the real centre of management, which has moved from lineage chiefs to the new people in charge of family farm lands, and a fragmentation of the lineages patrimonial holdings." (Mathieu et al, 2002). Tor and Christian add that "... the idea of land as a communal inheritance with deep spiritual significance has gradually lost currency... When 'multi-centric spheres' disintegrate, goods such as land that were previously only transferred through succession and reciprocal arrangements may enter the market economy." (Tor \& Christian, 2002). Such dealings in land matters in Zambia and elsewhere are not typical of traditional communities but are increasingly becoming common due to the introduction of a culture of private land holding rights through legislations such as the 1995 Lands Act.

\section{Conclusion}

From the discussion above it is evident that many individuals have obtained leasehold title for their pieces of land since 1995 than was the case before (over 80\%). Information exists that many pieces of customary land around Chibombo district have been converted to title since the enactment of the 1995 Lands Act. Furthermore, more men (over 90\%), than women (less than 5\%), have obtained title deeds for their pieces of land during the same period. Additionally, there are more people from urban areas (over $80 \%$ ) that have converted customary land to leasehold tenure than smallholder farmers (less that $12 \%$ ). The majority of urban individuals obtaining title to customary land in Chibombo district were mainly from Lusaka (over 90\%). 
In the pursuance of empowering individuals of all categories to have title to land, there is need to reconsider the title deed fees which seem to hinder many local people from paying for customary land conversions to title without selling part of their land to other people for cash. In the view of the researcher, this would help would increase the number of local people obtaining title to their land. Furthermore, there is need to maintain sizeable land space for the ever increasing village population in the study areas, and perhaps in the entire country. The current 250 hectares limited by the 1995 Lands Act is not being respected. Instituting a strict limit on the maximum size of land which chiefs can sell will reduce pressure on land, ensure availability of grazing land and minimize land conflicts among people both in the immediate and distant future.

Since restructuring land ownership rights through converting customary land to leasehold tenure is not unique to Zambia alone, there is need for the country to learn from other places how they have mitigated challenges emerging from such an undertaking. According to the World Bank (1994) Zambia would obtain useful lessons from emerging economies of Asia, Eastern Europe and Latin America on how to handle land matters. To permit conflicts on land may only lead to complex problems which are difficult to handle.

Owing to the nature of emerging challenges from land related issues among villagers, in Chibombo district, the author recommends further study of this topic to cover more areas and be made to include a longer period.

\section{Acknowledgements}

The author acknowledges help rendered to him by numerous individuals. Some individuals worth mentioning by name include Dr. Godfrey Muyoba, Dr. Foster Sakala, Mr. Tembo, Mr. Zimba, Mr. E. Kapungwe and Dr. D. Chibamba. The authors also thank family members for emotional and material support during the period of research. Chief Liteta and various headmen are greatly thanked for providing primary information for this work.

\section{References}

Adams, M. (2003). Land tenure policy and practice in Zambia: issues relating to the development of the agricultural sector. Draft document for DFID. Lusaka, Zambia.

Adams, M., Sibanda, S., \& Turner, S. (1999). Land tenure reform and rural livelihoods in southern Africa. Natural resource perspectives, $39,6$.

Andre, C. (2002). Custom, Contracts and Cadastres in North-west Rwanda. In A. B. Tor \& L. Christian (Eds.). Securing Land Rights in Africa in the European Journal of Development Research, A Frank Cass Journal, London.

Bruce, J., Kachamba, F., \& Hansungule, M. (1995). Land administration: Processes and constraints. Land Tenure, Land Markets and Institutional Transformation in Zambia, research paper, Land Tenure Centre, University of Wisconsin-Madison, 47-77.

Chibombo District Council. (2013). Information on Issued title deeds in the District for April and July, 2013. Chibombo.

Delville, P. L. (2002). When Farmers use 'Pieces of Paper' to record their land transactions in Francophone Rural Africa: Insights into the Dynamics of Institutional Innovation. In A. B. Tor \& L. Christian (Eds.). Securing Land Rights in Africa in the European Journal of Development Research. A Frank Cass Journal, London.

GRZ. (1985). Appendix 5 Administrative Circular. No. 1, 1985, Lusaka.

Ibid. (1980). The Colonial Foundations of Zambia's Land Tenure System. Lusaka: NECZAM.

Ibid. (1994). Changing Rural Land Use: Evidence of a Transition to Sedentary Agriculture among shifting cultivators of Solwezi District of Northwestern Province, Zambia. Review of Rural and Urban Planning in East and Southern African Journal.

Ibid. (1995). Lands Act, 1995. Lusaka: Government Printers.

Ibid. (1998). The Landmarks of Zambia's Land Tenure System: From Protectionism to Empowerment. Lusaka: University of Zambia.

Ibid. (2003a). Draft Land Policy. Lusaka: Government Printers.

Ibid. (2003b). Land and Natural Resources: Tenure Reform in Developing Countries: Lessons for Zambia. In V.C. Jha (Ed.), Land Degradation and Desertification. New Delhi: Rawat Publications.

Ibid. (2011). Sixth National Development Plan 2011-2015. Lusaka: Government Printers. 
Kajoba, G. (1994). Changing Perceptions on Agricultural Land Tenure under Commer-cialization among Small-Scale Farmers: The Case of Chinena Vil-lagein in Chicombo District (Kabwe Rural), Central Zambia.

Kajoba, G. M. (1997). Women and Land in Chinena Village, Chibombo District, Central Zambia: Vices from the Grassroots. Hitotsubashi journal of social studies, 29(1), 19-37.

Legislative Council Debates. (1930). Legislative Council Debates, 25th November, 1930.

Mathieu, P., Zongo, M., \& Pare, L. (2002). Monetary Land Transactions in Western Burkina Faso: Commoditization, Papers and Ambiguities. In A. B. Tor \& L. Christian (Eds.), Securing Land Rights in Africa in the European Journal of Development Research. A Frank Cass Journal, London.

MMD, (1996). MMD Manifesto. Lusaka: Government Printers.

Mvunga, M. P. (1977). Land Law and Policy in Zambia (Doctoral dissertation). University of London, London.

Odgaard, R. (2002). Scrambling for land in Tanzania: Process of Formalization and Legitimization of Land Rights. In A. B. Tor \& L. Christian (Eds.), Securing Land Rights in Africa in the European Journal of Development Research. A Frank Cass Journal, London.

Office of the Secretary General. (2011). 2011-2016 PF Manifesto. Lusaka: Government Printers.

Palmer, R. (1977). Land and Racial Domination in Rhodesia. London: Heinemann Educational Books Ltd.

Roth, M., Khan, A. M., \& Zulu, M. C. (2003). Legal Framework and Administration of Land Policy in Zambia. Lusaka: Government Printers.

Sichone, F. (2003). Land Administration in Zambia with particular reference to customary Land: Paper presented at a Seminar Organized by the Zambia Land Alliance. University of Zambia Senate Chamber, Lusaka.

Tor, A. B., \& Sjaastad, E. (2002). Race for the prize: Land Transactions and Rent Appropriation in Malian Cotton Zone. In A. B. Tor \& L. Christian (Eds.), Securing Land Rights in Africa in the European Journal of Development Research. A Frank Cass Journal, London.

Vlassenroot, K. (2003). Households Land Use Strategies in a Protected Crisis Context: Land Tenure, Conflict and Food Security in Eastern DRC. University of Ghent.

Wanyeki, M. (Ed.). (2003). Women and Land in Africa: Culture, Religion and Realizing Women's Rights. Cape Town: David Philip Publishers.

World Bank. (1989). Sub-Saharan Africa: From Crisis to Sustainable Growth. Washington D.C.: World Bank Publishers.

\section{Copyrights}

Copyright for this article is retained by the author(s), with first publication rights granted to the journal.

This is an open-access article distributed under the terms and conditions of the Creative Commons Attribution license (http://creativecommons.org/licenses/by/3.0/). 